\title{
Sandwich Structured Composites for Aeronautics: Methods of Manufacturing Affecting Some Mechanical Properties
}

\author{
Aneta Krzyżak, ${ }^{1}$ Michał Mazur, ${ }^{2}$ Mateusz Gajewski, ${ }^{2}$ Kazimierz Drozd, \\ Andrzej Komorek, ${ }^{1}$ and Paweł Przybylek ${ }^{1}$ \\ ${ }^{1}$ Aeronautics Faculty, Polish Air Force Academy, Ulica Dywizjonu 303, No. 35, 08-521 Dęblin, Poland \\ ${ }^{2}$ Mechanical Engineering Faculty, Lublin University of Technology, Ulica Nadbystrzycka 36, 20-618 Lublin, Poland \\ Correspondence should be addressed to Aneta Krzyżak; a.krzyzak@wsosp.pl
}

Received 9 February 2016; Revised 10 May 2016; Accepted 16 May 2016

Academic Editor: Linda L. Vahala

Copyright (C) 2016 Aneta Krzyżak et al. This is an open access article distributed under the Creative Commons Attribution License, which permits unrestricted use, distribution, and reproduction in any medium, provided the original work is properly cited.

Sandwich panels are composites which consist of two thin laminate outer skins and lightweight (e.g., honeycomb) thick core structure. Owing to the core structure, such composites are distinguished by stiffness. Despite the thickness of the core, sandwich composites are light and have a relatively high flexural strength. These composites have a spatial structure, which affects good thermal insulator properties. Sandwich panels are used in aeronautics, road vehicles, ships, and civil engineering. The mechanical properties of these composites are directly dependent on the properties of sandwich components and method of manufacturing. The paper presents some aspects of technology and its influence on mechanical properties of sandwich structure polymer composites. The sandwiches described in the paper were made by three different methods: hand lay-up, press method, and autoclave use. The samples of sandwiches were tested for failure caused by impact load. Sandwiches prepared in the same way were used for structural analysis of adhesive layer between panels and core. The results of research showed that the method of manufacturing, more precisely the pressure while forming sandwich panels, influences some mechanical properties of sandwich structured polymer composites such as flexural strength, impact strength, and compressive strength.

\section{Introduction}

In the case of modern engineering materials included in aeronautical materials, apart from strength properties, low weight of the final element is a crucial aspect. Such properties are directly connected with increasing operational properties of a given structure [1-3]. The most common purpose of manufacturing sandwich structures [4] is to obtain the greatest stiffness at minimum total density (average). All the mentioned parameters can have satisfactory values provided that the following conditions are met: produced structures will be distinguished by low quantity (density) of faults and lower amount of resin in the material. Improving these conditions of production is the scientific objective of developing more effective and advanced manufacturing methods. The continuity of the sandwich structure is especially significant in aeronautics, where a structural fault may lead to the failure of a flying object in consequence of subsequently happening events.
Values of distinctive parameters of an engineering material influence possibilities of its later use. A proper knowledge of the material's characteristics allows for producing an element of desirable properties with using specified resources, in relation to the applied technology and the purpose of use in a specific work environment. The essential characteristics of a structural material are its physical and mechanical properties. The knowledge of these characteristics allows for estimating the material's reaction to mechanical loads, which occur during its later use in a specific environment. Additionally, a proper durability of use is ensured [5-8].

Sandwich structures are light materials which show considerable stiffness and high ratio of strength in relation to weight. The main concept of the sandwich panel is that exterior surfaces transfer loads caused by bending (flexural load and compression), while the core transfers load caused by shearing. Accordingly, the work mode of the sandwich 
TABLE 1: Relative characteristics of sandwich structures in relation to solid material [9] (see Figure 10).

\begin{tabular}{lccc}
\hline Property & $\begin{array}{c}\text { Laminate } \\
\text { (skin) }\end{array}$ & $\begin{array}{c}\text { Sandwich } \\
\text { structure }\end{array}$ & $\begin{array}{c}\text { Thicker sandwich } \\
\text { structure }\end{array}$ \\
\hline Stiffness & 1.0 & 7.0 & 37.0 \\
Flexural strength & 1.0 & 3.5 & 9.2 \\
Weight & 1.0 & 1.04 & 1.06 \\
\hline
\end{tabular}

panel described macroscopically can be rightly compared to tasks performed by I-beam [9-11].

Sandwich composite materials belong to the group of anisotropic materials. It means that their strength properties change depending on the applied load. Using the knowledge concerning this anisotropy makes it possible to produce composite materials, which display specific properties in desired directions, depending on needs. They are developed depending on requirements posed in relation to a given composite. Moreover, these requirements are directly connected with the application of a given structure. The most significant requirements are as follows: stiffness, strength, specific volume, thermoinsulating power, acoustic resistance, ability to absorb energy, and hydrostatic weighing $[1,12-15]$.

The effects of innovative research performed on sandwich composite structures can be illustrated by the development of materials used in aeronautics. Initially, fillers in the form of balsa were used (military aircraft "de Havilland Mosquito"). Next, cellulose acetate foams and later honeycomb fillers $[11,16]$ were used. They are used for military purposes due to their nonmagnetic properties [11, 16, 17]. Skins are commonly made of standard materials used for structural laminates based on thermosetting resins and glass or carbon reinforcement. Skins can also be produced from thin plates made of thermoplastic materials of high resistance to impact but of low temperature of use [18] or metallic materials [19]. The so-called low density spacer materials, whose density is far lower than water density, are chosen to manufacture the core. These are most frequently polymer and ceramic foams, wood, and "honeycombs" which are materials made of elongated cells of a hexagonal or another shape.

The sandwich structure is most widely used in applications, in which stiffness of an element is particularly significant. Redoubling the core thickness (Table 1 and Figure 10) influences the stiffness of the sandwich panel more than seven times at barely $4 \%$ increase in the weight of the product. Increasing the core thickness of a panel by four times increases its stiffness more than 37 times at a barely $6 \%$ increase in the weight. Additionally, flexural strength improves. However, its change is smaller than in the case of comparing the changes in the element's stiffness [9].

The most frequently tested mechanical properties of sandwich composites are measurements of compressive strength [11, 20], three-point bending test [5, 21-23], and impact tests of a panel $[7,24]$. In the case of materials used in military technology, additionally ballistic tests are conducted [25]. Discovering values of these properties measured in simulated conditions of the element's work gives the possibility of relating them to real operation conditions and unambiguously determining the usefulness of a given material. It must be remembered that the material's properties determined in the course of mechanical tests are dependent on conditions, in which they have been determined. The obtained results are considerably influenced by the following factors: the applied samples (their shape and dimensions), the strength machine used (fixtures for samples mounted on it and also the stiffness of the measurement system), and the speed of changing load. The mentioned reasons allow for a conclusion that values determined as a result of mechanical tests are not of the characteristic material constants (coefficients), such as the density [26]. The mechanical properties of a sandwich composite depend on partial properties of components from which this composite has been constructed. Mechanical properties of foam and wood depend to a large extent on the density of these materials, speed of deformation, temperature, and humidity [27, 28]. Increased temperature of use and presence of steam have an adverse effect on mechanical properties of sandwich polymer composites. In the case of humidity, water absorption occurs in the material. If the composite has fiber reinforcement, absorption occurs as diffusion on the separation boundary between the fiber and matrix (in the interface). Long time of the material's exposure to humidity can cause its degradation, including cracking of the matrix and separation of fibers from it [29].

The flexural test of sandwich panels can be conducted on the basis of ASTM C 393-00 or PN-EN ISO 14125:2001 standards. These documents specify the following factors: shape and dimensions of samples, the way of conducting measurement, and methodology of analysing results. The flexural test can be performed by means of either the threeor four-point method. Four-point bending test is more rarely used despite its advantage-lack of destructive influence of the pressure stamp on the top part of the tested composite. This adverse influence occurs during a test conducted by means of the most commonly used method of three-point bending [21]. Consequently, samples subject to four-point bending test show increased flexural strength of the sandwich panel [30]. Failure of sandwich panels in the flexural test occurs mainly in the core of the material. It is a sliding crack in the core caused by shearing forces. Ultimate shear strength increases proportionally to the density of the used foam core and at decreasing the level of porosity. The increase in foam thickness does not improve this characteristic.

The increase in flexural strength of a sandwich panel can be obtained by using a skin of a material which has a greater stiffness or increasing its thickness [27]. If the foam core has low shear strength or is fragile, its failure can be immediate and unpredictable. When a material of high shear strength is used for the core, decohesion causing delamination between the core and outer structural layers of the panel can appear [31]. Destroying the core during a flexural test usually occurs directly under the load point, that is, a place where shearing forces and bending moment reach maximum values [32]. For the mentioned reasons, initiation, propagation, and stopping the development of cracking which leads to delamination are an essential aspect while testing sandwich structures [17]. 
One of the faults in layered materials, including sandwich type composites, is low resistance to delamination as a result of impact caused by small objects of low energy. Such an impact can lead to the separation of the outer structural layer from the core, which can facilitate the absorption of humidity by the material. Consequently, strength properties of a composite can significantly decrease. In the sandwich material, the laminate plays the most significant role in absorbing impact energy. On the other hand, the thickness of the core has influence on the decisive failure mechanism of the material [10]. The quality of the connection between the core and outer skin of the composite has a considerable influence on the impact strength of the layered material. It depends to a large extent on the used method of producing a panel [17].

Evaluation of the composite resistance to impact can be performed with the use of a hammer drill according to Charpy's method. There is a test with recording total energy and a test with a separate recording of initiation and crack development energy [33-35]. In the case of fiber composites, the latter recording provides a lot of information concerning the crack mechanism and gives a possibility of isolating the influence of components of a tested composite and structure of fibers on impact strength test [5].

\section{Materials and Methods of Experimental Tests}

2.1. The Objective of Research and Used Materials. Tests were aimed at determining the influence exerted by the production technology of sandwich laminates on chosen mechanical properties including structural characteristics occurring at the boundary of core stages and sandwich panel skins. Moreover, the objective of the tests was to analyse the process of developing cracks occurring after impact. The knowledge of such a process is indispensable for evaluating the degree of damage in sandwich laminates and the usefulness of laminates, especially used in aeronautics.

Sandwich panels of dimensions $500 \times 210 \times 10 \mathrm{~mm}$, from which samples for strength tests were cut, were produced by means of three methods: hand lay-up, press method, and autoclave use. These methods were chosen due to their wide application for producing composites used in road transport and aeronautics. Panels were built of a core in the form of polyurethane foam surrounded by a composite made of epoxy resin. Two types of materials were used for reinforcing the resin. Namely, foam sheet S63 (Connector) used for the core was characterized by the apparent density of $67.3 \mathrm{~kg} / \mathrm{m}^{3}$ and compressive strength which equaled $0.594 \mathrm{MPa}$ for measurements in the direction of cell increase during its production and 0.309 $\mathrm{MPa}$ for perpendicular directed measurements. According to the manufacturer's data, the foam S63 with 93\% cells of closed type showed water absorption at $1.6 \%$. Water absorption test was described by means of the PN-EN ISO 1609 test standard.

The following reinforcements were used in panel covers: two types of mats, EM 1002/300/125 and EM 1004/300/125, which differed in the type of silane preparation (resp., emulsion and powder) and two types of fabric STR 015-200-110 and
STR 010-300-125 which had surface weight, respectively, 200 and $300 \mathrm{~g} / \mathrm{m}^{2}$. The weave of both fabrics was the same type "one to one." It means that linear density of warp's roving and weft's roving was 200 or 300 depending on whether it was the first or second fabric. In all cases, glass fibers of $12 \mu \mathrm{m}$ diameter from E type glass produced by Krosglass S.A. were used as reinforcement.

The matrix of outer skins was made of low viscosity epoxy resin with a CES R70 symbol based on Bisphenol A/F (modified by means of an active two-function diluter) and CES H71 hardener. Such a composition is used to produce laminates from glass fibers, creating glue connection and impregnation of porous materials. Dosing CES R70 + CES H71 composition is $100: 54$ of weight parts (or 100:56 of volume parts). The estimated time of gelling $100 \mathrm{~g}$ of the mixture at a temperature of $293 \mathrm{~K}$ was approximately $30 \mathrm{~min}$. During the work with a mixture of resin and hardener, the minimum temperature of application was $281 \mathrm{~K}$ (optimal 291-293 K) at relative humidity not higher than $75 \%$. The lifetime of $100 \mathrm{~g}$ of CES R70 + CES H72 mixture was approximately 45 minutes at a temperature of $293 \mathrm{~K}$. The density of hardened resin was determined as $1.17 \mathrm{~g} / \mathrm{cm}^{3}$.

2.2. Methods of Producing Material for Tests. Every produced composite panel had a structure built of two glass-epoxy skins and core made of polyurethane foam. Every skin included one layer of reinforcement in the polymer matrix. In order to mark samples, symbols including one letter and one number were used. The letter referred to the method of contact laminating ( $\mathrm{T}$-composites reinforced with fabrics, $\mathrm{M}$-composites reinforced with mats), press method $(\mathrm{P})$, and producing with the use of autoclave (A). The number concerned the reinforcement used in panel skins. The fabric called STR 015-200-110 was replaced with number 2, whereas STR 010-300-125 fabric is referred to by means of number 3. EM 1002/300/125 and EM 1004/300/125 mats were marked with numbers 2 and 4 , respectively.

The most common methods of manufacturing sandwich structured composites were chosen. This allowed for focusing on the practical aspect of applying these methods. However, in order for such a comparison of methods to be possible, such types of resin and hardener were chosen to ensure the hardening of resin both at room temperature (hand lay-up and press methods) and at increased temperature (autoclave). The extent of resin crosslinking was not analysed.

2.2.1. Hand Lay-Up. For hand lay-up, a mixture of epoxy resin and hardener in a ratio 100:54 of weight parts (a digital scale with the accuracy of $0.01 \mathrm{~g}$ was used for measuring out) was prepared. The liquid was mixed for approximately 2 minutes until a clear consistency without visible streaks was obtained. After applying a small quantity of liquid, it was spread by means of a wide brush and hard roller, which facilitated squeezing air bubbles and even impregnation of the fabric.

Producing one structure required the following actions:

(1) simultaneous parallel impregnation of two fragments of the fabric, 
(2) impregnating the first element of reinforcement,

(3) placing and pressing the core to the first impregnated fabric,

(4) turning over the crosslinked fabric with the core and placing the second fragment of the fabric on the core and precise pressing.

2.2.2. Forming with the Use of the Press Method. Panels prepared by means of the contact method were subject to pressing. Next, plates were placed one on another and separated by means of stiff covers. Pressure of approximately $0.05 \mathrm{MPa}$ was used for pressing. It was close to but not higher that the foam's compressive strength. The pressure was maintained until the resin was hardened, that is, for approximately 24 hours.

2.2.3. Production Method with the Use of Autoclave. Similarly to pressing, spacer structures were prepared for production with autoclave by means of hand lay-up. Subsequently, two vacuum packages were prepared, each of which was composed of the following layers:

(1) formed composite (core and two skins),

(2) perforated separating foil (with a surplus of $3 \mathrm{~cm}$ on each side),

(3) on each side, two layers of absorbent fabric, whose purpose was to absorb surplus of resin,

(4) diaphragm foil, from which a vacuum bag was formed.

Insulating the diaphragm foil was performed by means of a special self-adhesive tape. Two holes were made in the bag, to which two valves were connected (their function was to connect the vacuum system and pressure control). The current control of insulation in the vacuum package was conducted by means of causing initial vacuum in the bag and observing changes in indications on the manometer. In the case of changing indication on the manometer, leakiness was located and eliminated. A detector (VacLeak LEQ-70) was used for accurately determining the place of leak. Placing the receiver closer to the source of leak resulted in obtaining greater amplification of sound. Prior to closing the autoclave, thermocouples were attached to the created packages in order to control temperature during the process (Figure 1). Crosslinking in the autoclave was conducted at a temperature of $333 \mathrm{~K}$ and underpressure of $0.08 \mathrm{MPa}(0.8 \mathrm{bar})$ maintained for 10 hours.

2.2.4. Procedure of Producing Sandwich Panels. Thickness measurement of composite panels showed that elements made of hand lay-up had the biggest thickness (Table 2). By comparing panels made of $200 \mathrm{~g} / \mathrm{m}^{2}$ (T2) fabric, it was determined that the thickness of composites produced in such a way was bigger by $2.91 \%$ than in the case of the press method and by $3.83 \%$ bigger than in the case of those produced by means of the autoclave method. In the case of bigger basis weight reinforcement (T3), an increase in
TABLE 2: Measurement results of sandwich panel samples used for tests.

\begin{tabular}{lcccc}
\hline $\begin{array}{l}\text { Production } \\
\text { method }\end{array}$ & $\begin{array}{c}\text { Type of } \\
\text { panel }\end{array}$ & $\begin{array}{c}\text { Average } \\
\text { thickness, } \\
\text { mm }\end{array}$ & $\begin{array}{c}\text { Standard } \\
\text { deviation, } \\
\text { mm }\end{array}$ & $\begin{array}{c}\text { Weight ratio of } \\
\text { reinforcement, \% }\end{array}$ \\
\hline \multirow{4}{*}{ Hand lay-up } & T2 & 10.96 & 0.20 & 16.26 \\
& T3 & 11.00 & 0.14 & 22.56 \\
& M2 & 12.42 & 0.13 & 10.03 \\
\hline \multirow{2}{*}{ Press } & M4 & 12.47 & 0.18 & 9.84 \\
\hline \multirow{2}{*}{ Autoclave } & P2 & 10.64 & 0.06 & 23.39 \\
& P3 & 10.84 & 0.05 & 26.26 \\
\hline
\end{tabular}

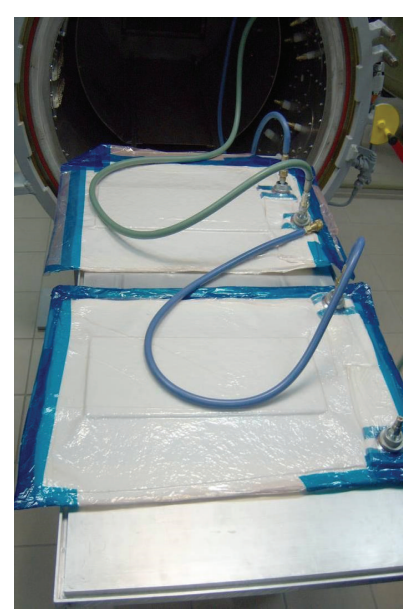

FIGURE 1: Vacuum packages before transport to autoclave.

thickness by $1.45 \%$ (press method) and $4.18 \%$ (autoclave) was observed. A visible increase in thickness was caused by a different quantity of resin in skins. Hand lay-up additionally caused obtaining a composite surface of samples, which also influenced the average thickness of laminate and was reflected in a several times greater value of standard deviation. The press and autoclave technologies, which were connected with exerting pressure and using a vacuum bag, facilitated a more even spreading of resin and easy removal of its surplus. Examples of photographs showing microscopic samples obtained by means of the hand lay-up (Figure 2), press method (Figure 3(a)), and autoclave use (Figure 3(b)) present structures of an individual composite.

Composite panels made of fabric reinforcement had a greater reinforcement weight ratio in comparison with material reinforced mats (Table 2, Figure 3). Composites produced by means of the hand lay-up method had a lower ratio of reinforcement than other laminates. Sandwich composites were characterized by a relatively low reinforcement ratio in skins. It was caused by the penetration of resin into the irregular cellular structure of the foam used for the core. 

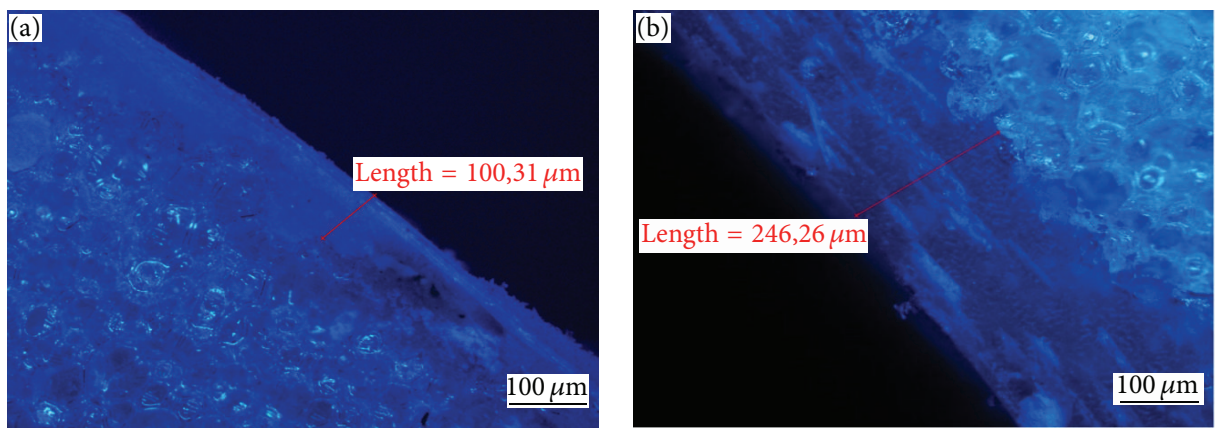

FIGURE 2: A comparison of thickness of outer structural skins in composites produced by means of contact reinforcement method with (a) STR 015-200-110 fabric and (b) EM 1004/300/125 mat.
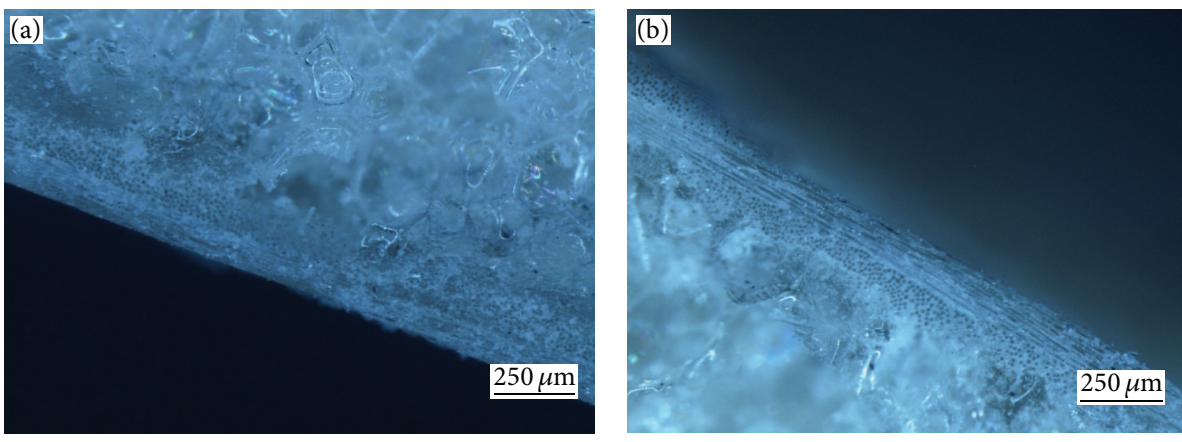

FIGURE 3: A comparison of structural skins in composites produced by means of (a) press method and (b) in the autoclave.

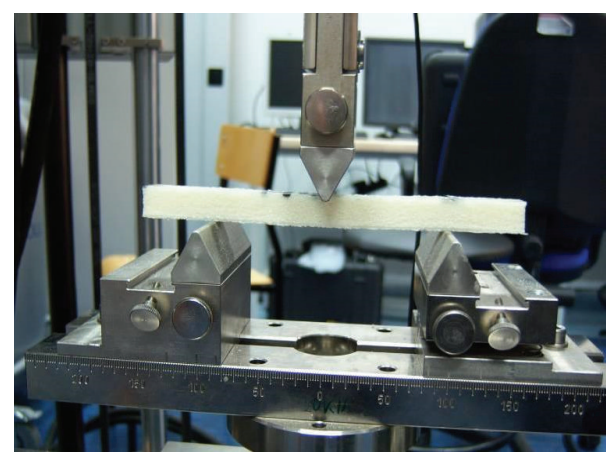

FIGURE 4: Way of mounting the sample while performing threepoint bending test.

\subsection{Methods of Determining Chosen Mechanical Properties}

2.3.1. Compressive Strength Tests. For the purpose of compressive strength tests, samples with the following parameters were used: length of $100 \mathrm{~mm}$, width ranging from 38.2 to $40.6 \mathrm{~mm}$, and thickness ranging from 10.9 to $12.8 \mathrm{~mm}$ depending on the type of material. Samples were cut with a DEDRA DED7731 cut-off machine with a diamond circular saw. Zwick Roell Z100 device was used for the test. Deflection velocity was $0.5 \mathrm{~mm} / \mathrm{min}$.

2.3.2. Flexural Strength Test. Samples for the three-point bending test (Figure 4) were prepared according to the PN-EN ISO 14125:2001 standard. Cuboid-shaped samples were used for the test with the following parameters: length of $160 \mathrm{~mm}$, width ranging from 13.32 to $13.95 \mathrm{~mm}$, and thickness ranging from 10.72 to 12.78 depending on the type of material. Flexural strength tests were performed with the use of Zwick Roell Z100 device. The test was conducted with a support spacing of $100 \mathrm{~mm}$. Velocity of the movement of the lifting beam was $10 \mathrm{~mm} / \mathrm{min}$, whereas velocity while determining the flexural modulus was $2 \mathrm{~mm} / \mathrm{min}$. The ray of used supports and stamp forcing deformation was $5 \mathrm{~mm}$. During the test, the stamp always exerted influence on the smooth side of the panel.

Flexural strength $\sigma_{f}$ was calculated on the basis of the following formula:

$$
\sigma_{f}=\frac{3 F L}{2 b h^{2}},
$$

where $\sigma_{f}$ is flexural strength (MPa); $F$ is load $(\mathrm{N}) ; L$ is support span (mm); $h$ is sample thickness measured in the direction of force impact ( $\mathrm{mm})$; and $b$ is sample width ( $\mathrm{mm})$.

For calculating the flexural modulus of elasticity, flexural maximum deflections $s^{\prime}$ and $s^{\prime \prime}$ were calculated. Equations used were

$$
\begin{aligned}
& s^{\prime}=\frac{\varepsilon_{f}^{\prime} L^{2}}{6 h}, \\
& s^{\prime \prime}=\frac{\varepsilon_{f}^{\prime \prime} L^{2}}{6 h},
\end{aligned}
$$

where $s^{\prime}$ and $s^{\prime \prime}$ are flexural maximum deflections in the half length of the beam $(\mathrm{mm})$ and $\varepsilon_{f}^{\prime}$ and $\varepsilon_{f}^{\prime \prime}$ are strain. 
TABLE 3: Measurement results of compressive strength tests.

\begin{tabular}{lcccccccc}
\hline Method of producing composite & \multicolumn{3}{c}{ Hand lay-up } & \multicolumn{2}{c}{ Press } & \multicolumn{2}{c}{ Autoclave } \\
\hline Type of panel & T2 & T3 & M2 & M4 & P2 & P3 & A3 \\
\hline E modulus at compression, MPa & 6.2 & 9.1 & 11 & 11.2 & 15.4 & 6.75 & 11.9 & 12.5 \\
Standard deviation of modulus, MPa & 2.06 & 3.38 & 1.34 & 2.25 & 2.33 & 0.315 & 1.15 & 1.442 \\
Compressive strength, MPa & 0.601 & 0.589 & 0.589 & 0.601 & 0.627 & 0.621 & 0.596 & 0.610 \\
Standard deviation of strength, MPa & 0.0051 & 0.0424 & 0.0265 & 0.0168 & 0.0182 & 0.0077 & 0.0061 & 0.0122 \\
Deflection, \% & 2.3 & 2.4 & 2.0 & 2.6 & 1.2 & 1.9 & 1.8 & 2.3 \\
Standard deviation of deflection, \% & 0.2 & 0.5 & 0.5 & 0.4 & 0.6 & 0.1 & 0.8 & 0.6 \\
\hline
\end{tabular}

TABLE 4: Measurement results of properties at flexural test.

\begin{tabular}{|c|c|c|c|c|c|c|c|c|}
\hline \multirow{2}{*}{$\begin{array}{l}\text { Method of producing composite } \\
\text { Type of panel }\end{array}$} & \multicolumn{4}{|c|}{ Hand lay-up } & \multicolumn{2}{|c|}{ Press } & \multicolumn{2}{|c|}{ Autoclave } \\
\hline & $\mathrm{T} 2$ & T3 & M2 & M4 & $\mathrm{P} 2$ & P3 & A2 & A3 \\
\hline Flexural strength, $\mathrm{MPa}$ & 3.67 & 3.72 & 6.22 & 7.26 & 3.03 & 3.54 & 3.18 & 4.02 \\
\hline Standard deviation of strength, $\mathrm{MPa}$ & 0.54 & 0.31 & 0.94 & 1.26 & 0.40 & 0.18 & 0.15 & 0.21 \\
\hline$E$ modulus, $\mathrm{MPa}$ & 359 & 350 & 301 & 301 & 343 & 350 & 360 & 402 \\
\hline Standard deviation of modulus, $\mathrm{MPa}$ & 59.5 & 31.8 & 24.2 & 24 & 36.9 & 10.8 & 28.2 & 10.2 \\
\hline Deflection at maximum strength, \% & 1.3 & 4.1 & 2.3 & 2.8 & 6.2 & 2.7 & 0.9 & 1.1 \\
\hline Standard deviation of deflection, $\%$ & 0.3 & 7.4 & 0.3 & 0.8 & 6.0 & 4.1 & 0.02 & 0.1 \\
\hline
\end{tabular}

The maximum deflections $s^{\prime}$ and $s^{\prime \prime}$ (2) correspond to the following adopted strain values: $\varepsilon_{f}^{\prime}=0.0005$ and $\varepsilon_{f}^{\prime \prime}=0.0025$ [23].

Flexural modulus of elasticity was calculated by means of the following equation:

$$
E_{f}=\frac{L^{3}}{4 b h^{3}}\left(\frac{\Delta F}{\Delta s}\right)
$$

where $E_{f}$ is flexural modulus of elasticity (MPa); $\Delta s$ is difference of flexural maximum deflections between $s^{\prime \prime}$ and $s^{\prime}$; and $\Delta F$ is difference between $F^{\prime \prime}$ load and $F^{\prime}$ load, at flexural deflection which equaled, respectively, $s^{\prime \prime}$ and $s^{\prime}$.

2.3.3. Impact Strength Test. Impact test by means of Charpy's method was conducted in accordance with the PN-EN ISO 179:2001 standard by using samples of the same dimensions as in the flexural test. Samples used for measuring impact test did not have a notch. For the test, a VEB Werkstoffprüfmaschinen Leipzig type 400/12 hammer with a support spacing of $70 \mathrm{~mm}$ and a pendulum of $0.4 \mathrm{~kJ}$ energy impact was used. The blade of the used hammer was wedgeshaped, with an internal angle of $30 \pm 1^{\circ}$ and a rounding of an $r=2 \pm 0.5 \mathrm{~mm}$ ray. The test was performed at room temperature. During the test, energy used for the sample failure was recorded. Energy measurements during the test made it possible to determine impact strength of the material, which is work used for dynamic breaking of a sample without a notch related to the initial cross-sectional area of the sample in the point of fracture. Impact was calculated by means of the equation given below:

$$
a_{n}=\frac{A_{n}}{b t} \cdot 10^{3} \mathrm{~kJ} / \mathrm{m}^{2}
$$

where $A_{n}$ is impact energy used for breaking the sample, $\mathrm{kJ}$; $b$ is sample width, $\mathrm{mm}$; and $t$ is sample thickness, $\mathrm{mm}$.

2.4. Macroscopic Analysis of Structure. Observations of the structure were performed after tests of mechanical properties were conducted. For this purpose, Nikon SMZ 1500 stereoscopic microscope with a magnification range from $0.75 \mathrm{x}$ to $11.25 \mathrm{x}$ was used. By means of a Kodak Easyshare v803 digital camera mounted on a tripod stand, photos visible in the microscope lens were taken in the macro mode. Tests made it possible to evaluate the quality of produced materials and identification of technological structural faults.

\section{Test Results and Their Analysis}

3.1. Compressive Strength Test. Table 3 presents average test results obtained as a result of the compression trial. The obtained value of compressive strength for all panels was in accordance with the one estimated by the foam producer and was approximately $0.59 \mathrm{MPa}$ (Table 3 ). A similar deformation, independent of the composite type reached approximately a $2 \%$ level. Nevertheless, the influence of reinforcement and method of producing a composite on the $E$ modulus value at compression was proved. The lowest $E$ modulus value at compression was recorded for composites reinforced with fabrics, which were produced by means of hand lay-up.

3.2. Flexural Strength Test. Results of the flexural strength test are presented in Table 4. A greater stiffness is characteristic of materials, whose outer structural skins include fabric reinforcement. The greatest flexural strength was observed for composites with mat reinforcement. Probably it resulted from the occurrence of bigger amount of resin between 


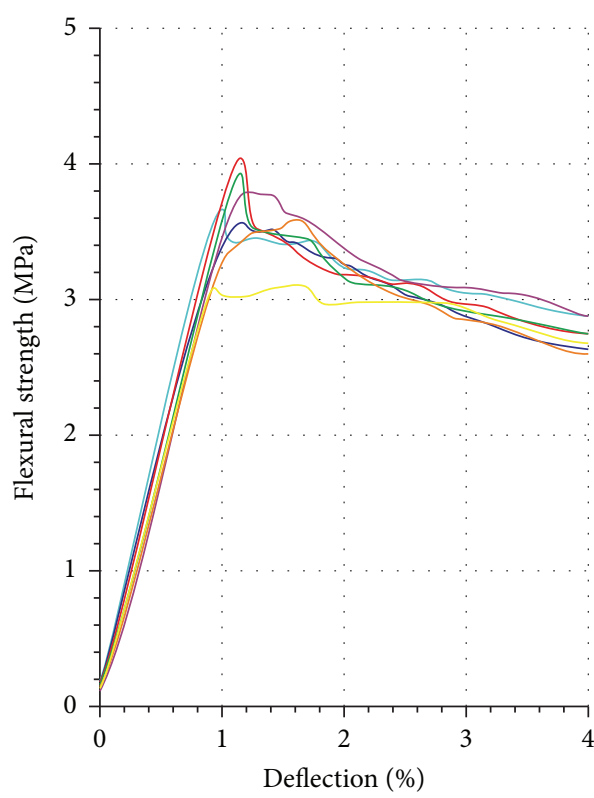

(a)

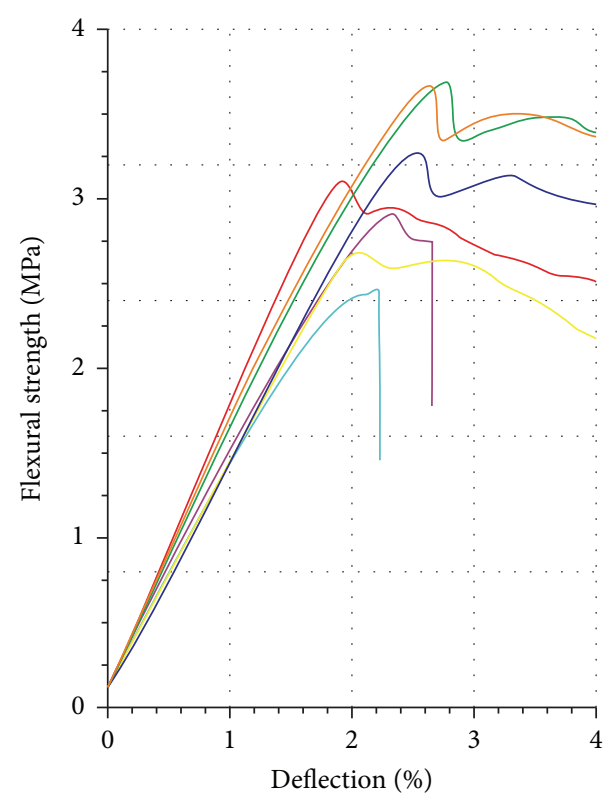

(b)

FIGURE 5: Examples of flexural characteristics of composite bending (a) T3 and (b) M2.

loosely placed fibers (in fabrics, they were tightly placed). As shown by tests of the structure, the thickness of the outer structural layer made of mat was twice bigger than in case of the outer layer made of fabric. In mats, fibers are placed in many directions, which can also contribute to this effect.

Figure 5 presents examples of tension and deflection characteristics obtained during a three-point bending trial for some tested materials. The beginning of the deflection curve was an increasing linear function, which then changed into a slightly falling curve (Figure 5(a)). At reaching a maximum value of load, there was a failure of sample and change of the function's type into the nonlinear one was accompanied by frequently quite rapid decrease in force value. In some cases (Figure 5(b)), after lowering tension, there was a nonlinear phase of its slight increase, yet it failed to reach a value close to the previous maximum one. Then, the curve took the form of a decreasing function. Composites produced by means of the autoclave method showed the greatest flexural strength. Additionally, they were distinguished by high repeatability of results (low standard deviation).

In most cases, tested panels did not show decohesive failure. Nevertheless, a failure of core foam in the place of contact of the load stamp directly under the structural layer (skin) and core deflection were observed. Figure 6(a) presents an example of a sample reinforced with fabric after the flexural test.

In several samples reinforced with a mat, failure caused by cracking of the core was observed. Crack initiation occurred in the place where there was a connection core, the structural layer directly under the stamp, which was a load on the sample. Propagation of crack in the layer of connecting composites occurred. It was further followed by delamination. After reaching a certain length of delamination, there was a
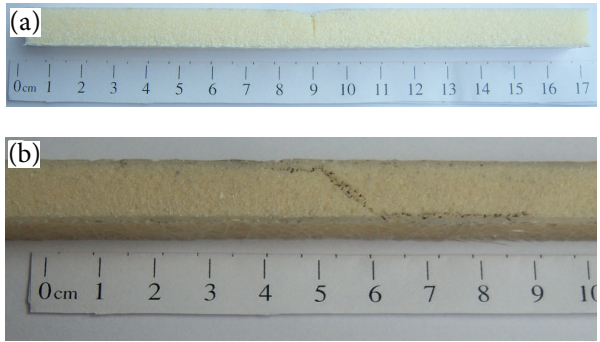

FIGURE 6: Examples of panels produced after conducting flexural strength test of composites reinforced with (a) fabric and (b) mat.

transverse cracking of the core at a $45^{\circ}$ angle to the upper structural layer and delamination between the core and the bottom skin of laminate. Delamination occurred only in certain places and stopped after reaching a certain length. Figure 6(b) illustrates failure of a sample reinforced with a mat with a visible cracking of the core.

3.3. Impact Test. Values presented in Table 4 indicate that the greatest value of resistance to impact was observed among composites, whose outer structural layers were reinforced with fabric and produced by means of the autoclave method. Obtained from results, higher standard deviation for impact strength of materials made of fabric proves that there is a greater diversity in the quality of producing these samples as compared to materials with mats. It can be caused by the occurrence of faults in the structure of these materials. Composites reinforced with a mat were distinguished by grater thickness in relation to materials with fabric, yet their impact strength was visibly lower (Table 5). It was probably 
TABLE 5: Results of impact strength according to Charpy's method.

\begin{tabular}{lccc}
\hline $\begin{array}{l}\text { Method of } \\
\text { producing } \\
\text { composite }\end{array}$ & $\begin{array}{c}\text { Type of } \\
\text { panel }\end{array}$ & $\begin{array}{c}\text { Average impact } \\
\text { strength, } \mathrm{kJ} / \mathrm{m}^{2}\end{array}$ & $\begin{array}{c}\text { Standard } \\
\text { deviation, } \mathrm{kJ} / \mathrm{m}^{2}\end{array}$ \\
\hline \multirow{4}{*}{ Hand lay-up } & M2 & 10.15 & 1.35 \\
& M4 & 10.42 & 1.93 \\
& T2 & 11.48 & 5.61 \\
\hline \multirow{2}{*}{ Press } & T3 & 12.87 & 4.47 \\
\hline \multirow{2}{*}{ Autoclave } & P2 & 19.04 & 3.05 \\
& P3 & 13.25 & 5.32 \\
\hline
\end{tabular}
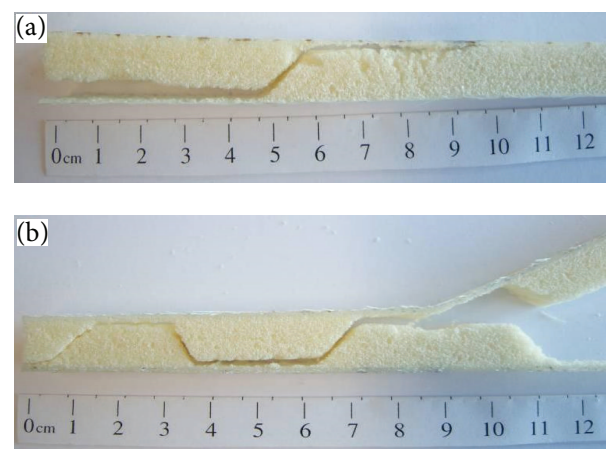

FIGURE 7: Examples of impact test failure in hand lay-up samples reinforced with (a) STR 015-300-110 fabric and (b) EM 1002/300/125 mat.

caused by a lower ratio of the reinforcement weight to resin weight in structural layers (Table 2). Moreover, the epoxy resin was a fragile material, which together with a bigger amount of defects (air bubbles) influenced the much lower impact resistance of composites manufactured by hand layup method. Additionally, the surface of adhesive resin and foam connection in composites produced by means of the press and autoclave methods probably was bigger than in the case of composites produced by hand lay-up method. During the manufacture by means of the press and autoclave methods, there appeared a force pressing outer layers of the reinforcement to the composite core.

Both groups of materials (reinforced with mat and fabric, produced by hand lay-up method) mostly showed the same type of failure, as a result of which there was a delamination of the sample from the place of impact to its end (Figure 7). Crack initiation occurred directly in the place of the hammer's impact, on the boundary of the connection between the structural laminate layer and core. At this stage, the crack was of adhesive nature. At certain length of its propagation, there was cracking of the core at a $45^{\circ}$ angle to the skin and there were decohesion and delamination of the bottom skin of the sandwich composite as shown in Figure 7(a). The presented form of destruction is confirmed by [17].

As for composites reinforced with EM 1002/300/125W, in a few cases, there was a complete separation of bottom layer of the laminate from the core material. Simultaneously, a

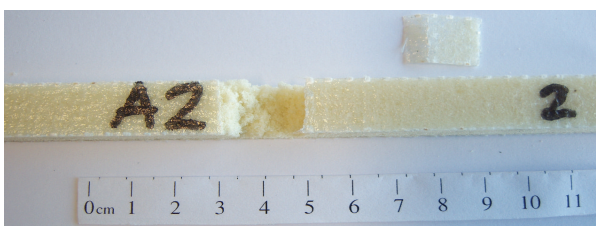

FIgURE 8: Impact failure observed for composites produced by the autoclave method (A2).
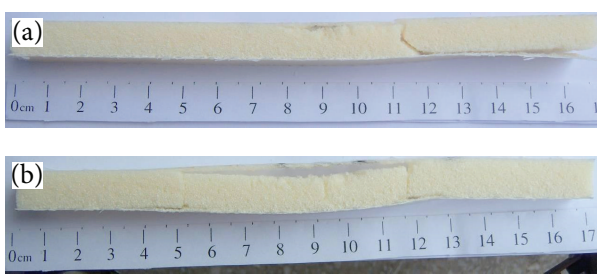

FIGURE 9: Samples of pressed composites P2 (a) and P3 (b) damaged during impact strength test.

decohesion of the core occurred in many places (Figure 7(b)). Lack of total separation of the laminate and core proves a good quality of the adhesive connection between epoxy resin and polyurethane core. As for samples with EM 1004/300/125 mat and STR 015-200-110 fabric, in a few cases, local failure of the core in the place of the hammer's impact and a simultaneous delamination of the sample were observed.

All composites produced by means of the autoclave including a reinforcement with a fabric of a $200 \mathrm{~g} / \mathrm{m}^{2}$ (A2) basis weight showed a destruction of the skin with a loss of the core in the area of the hammer's impact (Figure 8). On the lost parts of fabric, an even layer of foam was also observed. Furthermore, those composites were characterized by the greatest average value of impact strength and the lowest standard deviation among those with fabric reinforcement (Table 5). The reason for the occurrence of a similar failure mechanism of samples and low variation of results was a high repeatability of producing composites in the autoclave. Distinctive failure of materials and greatest impact strength could have been caused by low basis weight of the fabric and low content of resin in the reinforcement.

During the impact test of composites with lower basis weight of the fabric, the skin broke in two cases. Simultaneously, there was no loss of the core and skin in the area of the hammer's impact, which occurred during the test of the composite reinforced with A2 material. The average results showed that the value of impact strength is lower by $23.25 \%$ than the similar average for A2 material. The lower value of impact strength can be explained by a higher ratio of resin in skins.

Materials produced by the press method, independently of the type of used fabric, were distinguished by visible delamination on the boundary of the core and skin (Figure 9). Furthermore, in pressed composites, cracking of the composite core parallel to the direction of impact was distinctive. 


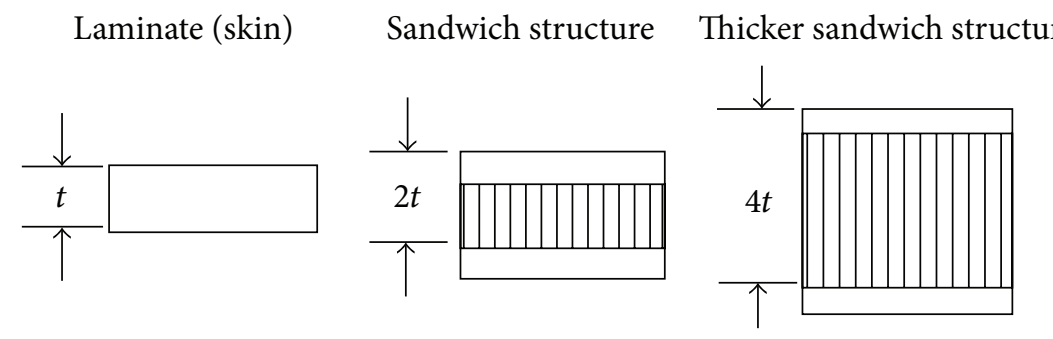

FIGURE 10: Global structure of different types of laminates [9].

\section{Conclusions}

The strength of sandwich materials in relation to the impact strength to a large extent depends on the properties of the laminate in the structural skin and its connection with the core of the sandwich composite. The laminate plays the most significant role in impact energy absorption during the trial. On the basis of conducted analyses, it can be concluded that materials with a reinforcement that has a higher ratio of reinforcement weight to resin weight are distinguished by a higher impact strength.

For materials with a mat reinforcement, higher values of the $E$ modulus were obtained. The autoclave method allowed for the production of composites distinguished by the highest values of impact strength and elasticity modulus. Using the autoclave influenced obtaining materials distinguished by maintained high repeatability. Composites produced by this method were distinguished by nearly total lack of structural discontinuity and visually high quality of surface (smoothness and homogeneity).

The presence of surface faults (air bubbles, surface irregularities) in the case of using the hand lay-up technology resulted in obtaining strength test results characterized by a high variation. Local lack of foam on the skin in the case of samples produced by means of the contact method indicates an inaccurate connection of the core with the skin.

The failure mechanism influenced by impact strength force pointed to the necessity of exchanging sandwich panels. Additionally, in the case of composites obtained by means of the press method at low impact forces, there occurred delamination between the skin and core as well as a failure of the core's continuity. Nevertheless, the structure of the skin was not destroyed. Such a lack of visible damage on the surface of the laminate, in some cases, can be a beneficial phenomenon. However, in the case of composites produced by means of the autoclave method, sudden contact impact of high force caused a separation of the skin fragment from the composite in the place where the force occurred.

The method of producing sandwich composites in aeronautics is determined by labor intensity and quality of producing a composite. Values of distinctive strength parameters point to an efficient use of the press method as a cheaper alternative to the autoclave method. Mechanical properties of sandwich composites produced by means of both methods are comparable.

\section{Competing Interests}

The authors declare that they have no competing interests.

\section{References}

[1] F. C. Campbell, Manufacturing Technology for Aerospace Structural Materials, Elsevier, London, UK, 2006.

[2] A. Krzyżak and D. Vališ, "Selected safety aspects of polymer composites with natural fibres," in Safety and Reliability: Methodology and Applications, T. Nowakowski, M. Młyńczak, A. Jodejko-Pietruczuk, and S. Werbińska-Wojciechowska, Eds., pp. 903-909, Taylor \& Francis Group, London, UK, 2015.

[3] M. Landowski, M. K. Budzik, and K. Imielińska, "Wpływ metody wytwarzania na właściwości laminatów poliestrowo/ szklanych do budowy małych jednostek pływających," Inżynieria Materiałowa, vol. 5, pp. 868-872, 2001.

[4] ASTM Standard C 274-99, Standard Terminology of Structural Sandwich Constructions, American Society for Testing Materials, 2000.

[5] A. I. Boczkowska, Kompozyty, Oficyna Wydawnicza Politechniki Warszawskiej, Warszawa, Poland, 2003.

[6] W. Królikowski, Polimerowe Kompozyty Konstrukcyjne, Wydawnictwo Naukowe PWN, Warszawa, Poland, 2012.

[7] H. Leda, Kompozyty Polimerowe z Włóknami Ciągłymi: Wytwarzanie, Właściwości, Stosowanie, Wydawnictwo Politechniki Poznańskiej, Poznań, Poland, 2006.

[8] D. Zuchowska, Polimery Konstrukcyjne, Wydawnictwo Naukowo Techniczne, Warszawa, Poland, 2000.

[9] F. C. Campbell, Structural Composite Materials, ASM International, Novelty, Ohio, 2010.

[10] A. Muc and R. Nogowczyk, "Formy zniszczenia konstrukcji sandwiczowych z okładzinami wykonanymi z kompozytów," Composites, vol. 5, no. 4, pp. 31-36, 2005.

[11] S. Ochelski and T. Niezgoda, "Kompozytowe konstrukcje pochłaniające energię uderzenia," Przegląd Mechaniczny, vol. 1, pp. 21-28, 2007.

[12] F. C. Campbell, Manufacturing Processes for Advanced Composites, Elsevier, London, UK, 2004.

[13] M. A. Dweib, B. Hu, A. O’Donnell, H. W. Shenton, and R. P. Wool, "All natural composite sandwich beams for structural applications," Composite Structures, vol. 63, no. 2, pp. 147-157, 2004.

[14] A. Jüngert, "Damage detection in wind turbine blades using two different acoustic techniques," in Proceedings of the 7th fib $P h D$ Symposium, Journal of Nondestructive Testing, Stuttgart, Germany, September 2008. 
[15] A. P. Mouritz and A. G. Gibson, Fire Properties of Polymer Composite Materials, Springer, 2006.

[16] L. J. Gibson and M. F. Ashby, Cellular Solids. Structure and Properties, Cambridge University Press, 1997.

[17] R. Wojtyra and K. Imielińska, "Badania pękania udarowego w konstrukcjach przekładkowych poliestrowo-szklanych z rdzeniem z pianki PVC," Kompozyty, vol. 7, no. 3, pp. 140-144, 2007.

[18] H. Ning, G. M. Janowski, U. K. Vaidya, and G. Husman, "Thermoplastic sandwich structure design and manufacturing for the body panel of mass transit vehicle," Composite Structures, vol. 80, no. 1, pp. 82-91, 2007.

[19] A. G. Mamalis, K. N. Spentzas, N. G. Pantelelis, D. E. Manolakos, and M. B. Ioannidis, "A new hybrid concept for sandwich structures," Composite Structures, vol. 83, no. 4, pp. 335-340, 2008.

[20] ASTM, "Standard test method for flatwise compressive properties of sandwich cores," ASTM Standard C 365-03, American Society for Testing Materials, 2005.

[21] ASTM Standard C 393-00, Standard Test Method for Flexural Properties of Sandwich Constructions, American Society for Testing Materials, 2000.

[22] T. S. Gates, X. Su, F. Abdi, G. M. Odegard, and H. M. Herring, "Facesheet delamination of composite sandwich materials at cryogenic temperatures," Composites Science and Technology, vol. 66, no. 14, pp. 2423-2435, 2006.

[23] ISO, "Composite materials reinforced with fiber. Marking properties at flexural test," PN-EN ISO 14125:2001, ISO, 2001.

[24] ISO, "Marking impact by means of Charpy's method," PN-EN ISO 179:2001, 2001.

[25] J. Christopherson, M. Mahinfalah, G. N. Jazar, and M. R. Aagaah, "An investigation on the effect of a small mass impact on sandwich composite plates," Composite Structures, vol. 67, no. 3, pp. 299-306, 2005.

[26] M. Blicharski, Inżynieria Materiałowa, Wydawnictwo Naukowo-Techniczne, Warszawa, Poland, 2014.

[27] S. Y. Shen, F. J. Masters, H. L. Upjohn, and C. C. Ferraro, "Mechanical resistance properties of FRP/polyol-isocyanate foam sandwich panels," Composite Structures, vol. 99, pp. 419432, 2013.

[28] M. Osei-Antwi, J. De Castro, A. P. Vassilopoulos, and T. Keller, "Shear mechanical characterization of balsa wood as core material of composite sandwich panels," Construction and Building Materials, vol. 41, pp. 231-238, 2013.

[29] F. Avilés and M. Aguilar-Montero, "Mechanical degradation of foam-cored sandwich materials exposed to high moisture," Composite Structures, vol. 92, no. 1, pp. 122-129, 2010.

[30] A. Corigliano, E. Rizzi, and E. Papa, "Experimental characterization and numerical simulations of a syntactic-foam/glassfibre composite sandwich," Composites Science and Technology, vol. 60, no. 11, pp. 2169-2180, 2000.

[31] G. Belingardi, M. P. Cavatorta, and R. Duella, "Material characterization of a composite-foam sandwich for the front structure of a high speed train," Composite Structures, vol. 61, no. 1-2, pp. 13-25, 2003.

[32] A. C. Manalo, "Behaviour of fibre composite sandwich structures under short and asymmetrical beam shear tests," Composite Structures, vol. 99, pp. 339-349, 2013.

[33] D. Feng and F. Aymerich, "Damage prediction in composite sandwich panels subjected to low-velocity impact," Composites Part A: Applied Science and Manufacturing, vol. 52, pp. 12-22, 2013.
[34] A. Mostafa, K. Shankar, and E. V. Morozov, "Insight into the shear behaviour of composite sandwich panels with foam core," Materials and Design, vol. 50, pp. 92-101, 2013.

[35] P. Qiao and M. Yang, "Impact analysis of fiber reinforced polymer honeycomb composite sandwich beams," Composites Part B: Engineering, vol. 38, no. 5-6, pp. 739-750, 2007. 


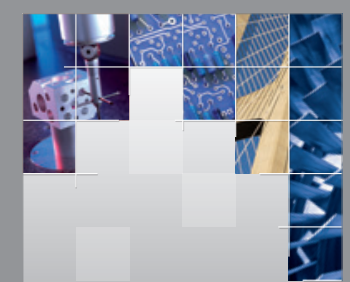

\section{Enfincering}
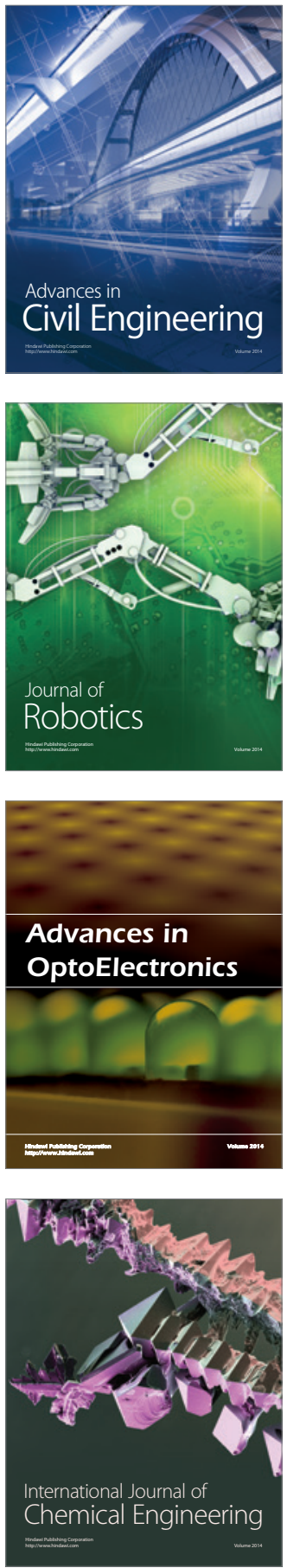

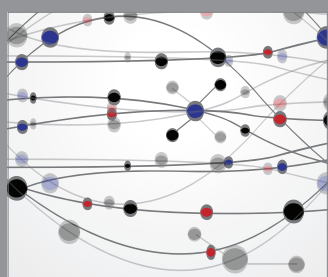

The Scientific World Journal

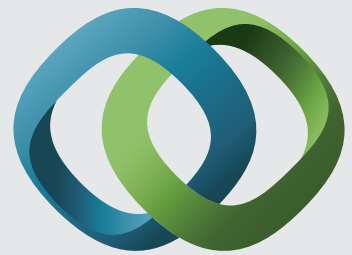

\section{Hindawi}

Submit your manuscripts at

http://www.hindawi.com
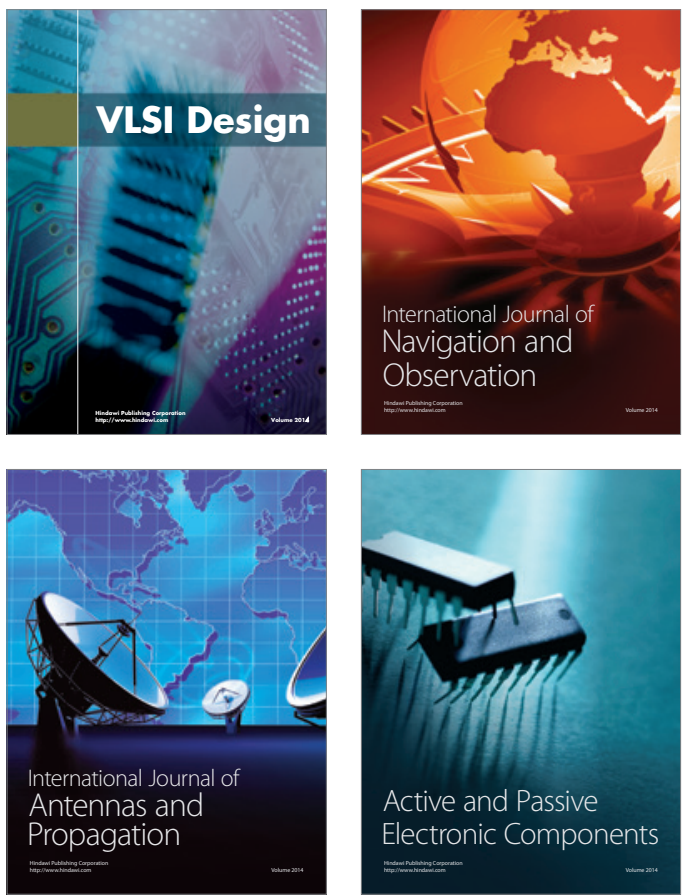
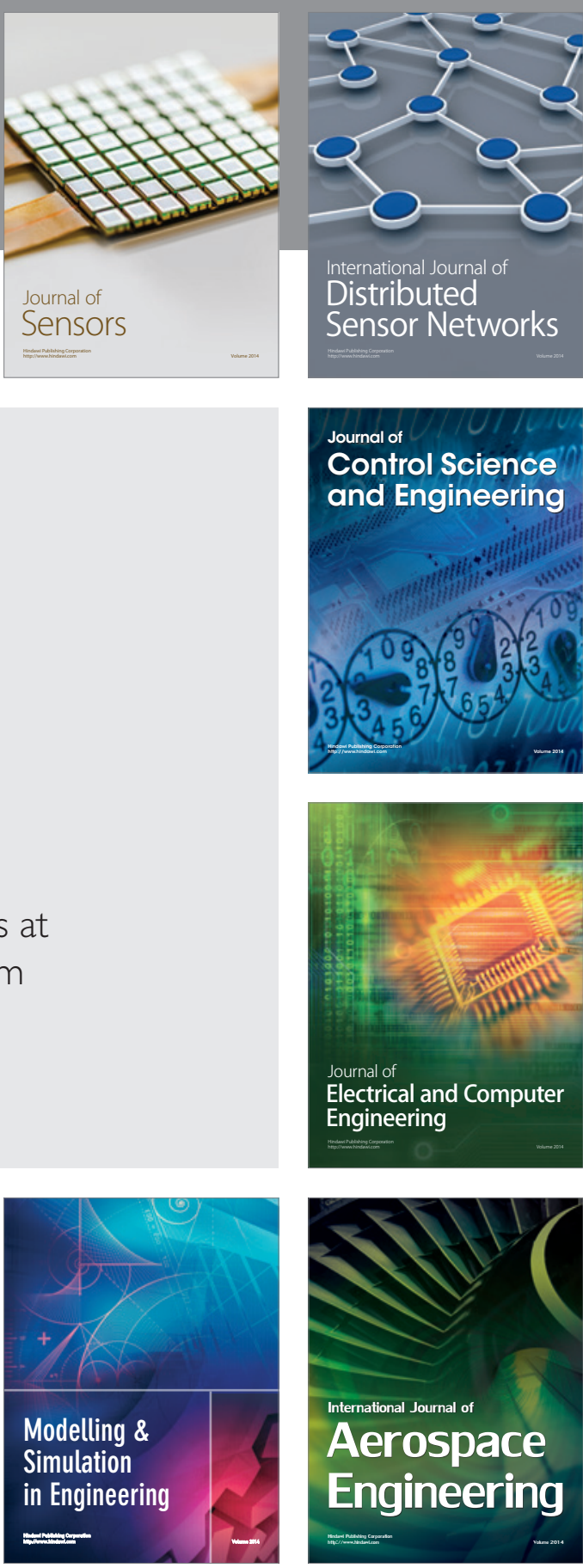

International Journal of

Distributed

Sensor Networks

Journal of

Control Science

and Engineering
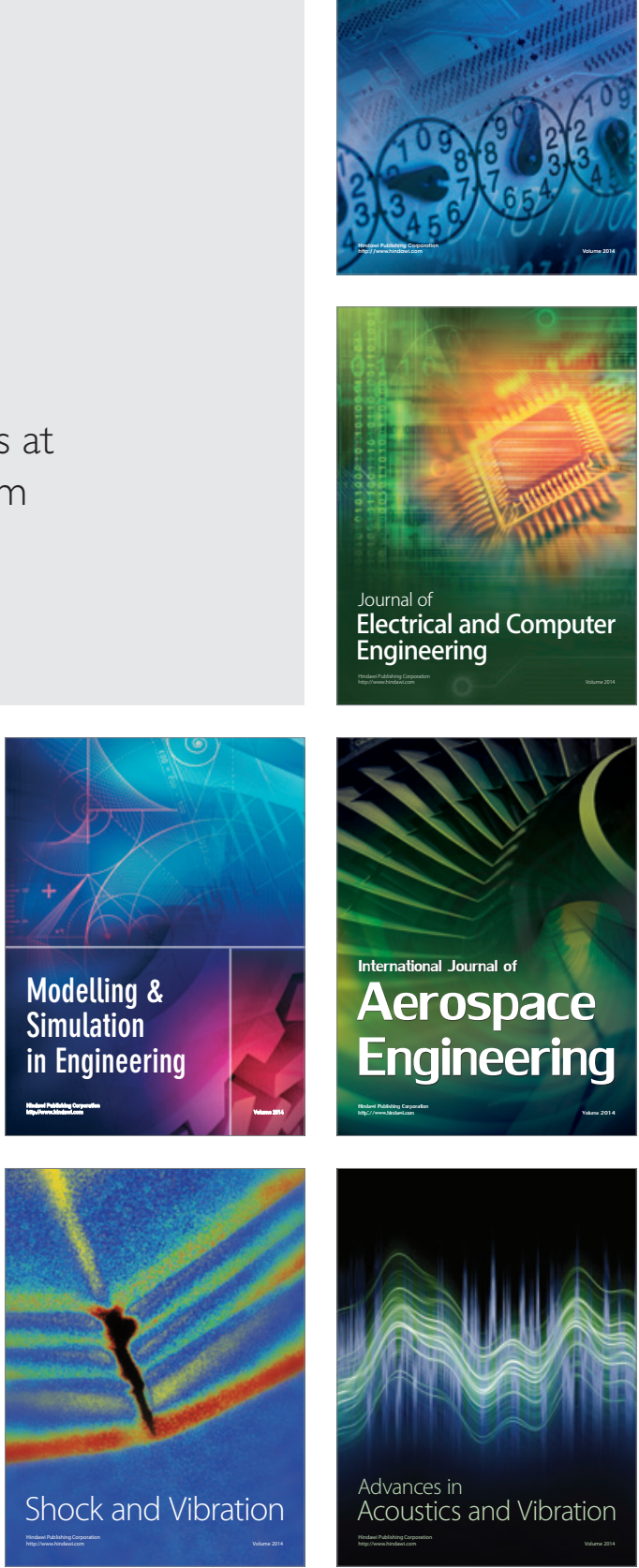